\title{
Perancangan E-Commerce Sebagai Media Pemasaran Kerajian Bambu
}

\author{
F. Lia Dwi Cahyanti*1 ${ }^{1}$, Fajar Sarasati ${ }^{2}$ Widiastuti $^{3}$, Elly Firasari ${ }^{4}$ \\ ${ }^{1,2,4}$ Program Studi Sistem Informasi, Universitas Nusa Mandiri \\ ${ }^{3}$ Program Studi Informatika, Universitas Nusa Mandiri \\ email: flia.fdc@nusamandiri.ac.id ${ }^{1}$, fajar.fss@nusamandiri.ac.id ${ }^{2}$, \\ widiastuti.wtu@nusamandiri.ac.id ${ }^{3}$, elly.efa@nusamandiri.ac.id ${ }^{4}$
}

(Received: 31 Maret 2021/ Accepted: 30 April 2021 / Published Online: 20 Juni 2021)

\begin{abstract}
Abstrak
Pada saat ini perkembangan ekonomi di Indonesia sangat pesat, hal ini terbukti dengan banyak bermunculan bidang-bidang usaha yang baru dirintis salah satunya perusahaan yang bergerang dibidang perdagangan. Setiap perusahaan melakukan berbagai upaya agar membuat perusahaan tersebut tetap berkembang. UKM Kerajinan Bambu Brajan yang berlokasi di Sleman Yogyakarta mengalami permasalahan dalam kegiatan promosi dan penjualan produk yang masih tradisional dan manual. Tujuan dari penelitian ini adalah untuk merancang e-commerce sebagai media pemasaran kerajinan bambu pada UKM di desa Brajan. Dengan dibuatnya website e-commerce sebagai pemasaran produk diharapkan mampu membantu memasarkan produk sehingga dapat dikenal masyarakat luas. Penelitian ini menggunakan metode waterfall dalam pembuatan website sehingga berurutan dan sistematis. Penelitian ini menghasilkan sebuah website ecommerce yang sudah diuji kelayakan nya menggunakan metode black box testing. Website ini memberikan informasi kepada konsumen mengenai produk yang dijual pada UKM Kerajinan Bambu Brajan, serta memberikan kemudahan pihak UKM dalam proses penjualan serta pemasaran produk.
\end{abstract}

Kata kunci: E-Commerce, Media, Perancangan, Pemasaran, UKM

\begin{abstract}
At this time progress economic in Indonesia is very rapidly, This is evidenced by the emergence of many newly pioneered business fields one of which is a company engaged in marketing. Each Company makes various efforts to keep the company be growing. UKM Kerajinan Bambu Brajan in Sleman Yogyakarta has a problem's promotion activities and product sales that are still traditional and manual. The purpose of this study is to design e-commerce as a traffic bamboo handicrafts on UKM in Brajan village. With the creation of the e-commerce website as the marketing of products is expected to help traffic the product so that it can be widely known to the public. The waterfall model is what is used to design this product in systematic steps. This study produces a ecommerce website that has been tested for its feasibility using the black box testing method. This Website provides information to consumers about the products in UKM Kerajinan Bambu Brajan, as well as provides a facility of the UKM in the process of selling and marketing products.
\end{abstract}

Keywords: E-Commerce, Media, Design, Marketing, UKM

\section{PENDAHULUAN}

Perkembangan ekonomi di Indonesia sangat pesat, hal ini terbukti dengan munculnya bidang-bidang usaha yang baru dirintis. Kemunculan beberapa usaha baru ini cukup dapat mengatasi permasalahan yang muncul di negara ini, yaitu banyaknya pengangguran. Salah satu bidang usaha yang baru muncul yaitu perusahaan yang bergerak dibidang perdagangan, Sebagai dampak dari adanya bidang usaha yang baru, tentunya setiap perusahaan melakukan berbagai upaya agar membuat perusahaan tersebut tetap berkembang dan dapat bersaing 
dengan perusahan-perusahan lain. Permasalahan terbesar yang dialami usaha mikro Usaha Kecil Menegah (UKM) yakni pemasaran. Dalam memasarkan produknya agar lebih luas, usaha mikro biasanya menggunakan tenaga tengkulak (pengepul) untuk menekan harga jual mereka, padahal hal tersebut menyebabkan harga jual produk yang mereka berikan lebih rendah dibanding harga pasaran (Triyaningsih, 2012).

Seperti UKM Kerajinan Bambu Brajan di Dukuh Brajan, Desa Sendangagung, Kecamatan Minggir, Kabupaten Sleman yang mayoritas masih menggunakan penjualan tradisional dan belum dapat beralih ke sistem komputerisasi penjualan produk-produk mereka. Hal tersebut dikarenakan beberapa kendala diantaranya adalah SDM yang belum memahami internet, penjualan masih dilakukan door to door, hanya mengandalkan reseller dan event seperti pameran. Produk UKM Kerajiana Bambu Brajan berkualitas ekspor karena produk yang dihasilkan sangat unik serta bernilai jual tinggi. Strategi yang dilakukan untuk membantu pemasaran masih dirasa kurang membantu meningkatkan produktivitas dan pemasarannya.

Berdasarkan hasil observasi dan wawancara secara langsung pada UKM Kerajinan Bambu Brajan, cara promosi dan penjualan yang masih tradisional dan manual mengakibatkan beberapa masalah yaitu produk kurang dikenal masyarakt luas, pemasaran dan penjualan produk jangkauannya sempit serta omset penjualan yang belum sesuai target yang ditentukan. Oleh sebab itu akan dibuatlah website e-commerce untuk mengatasi masalah promosi dan penjualan produk. Website yang dibangun pada penelitian ini berbasis ecommerce menurut (Handayani, 2018) e-commerce merupakan suatu aktivitas atau kegiatan jual beli yang dilakukan secara online melalui situs atau website. Menurut (Soejono et al, 2018) website merupakan sarana untuk mengenalkan perusahaan dan produknya kepada masyarakat secara lebih detil. Untuk mengetahui fungsi apa yang ada didalam sistem informasi dan siapa saja yang berhak menggunakan fungsi-fungsi tersebut maka digunakan Use Case Diagram Use Case itu sendiri merupakan abstraksi dari interaksi antara sistem dan actor (Tohari, 2014). sedangkan menurut (Purwati \& Hasan, 2016) Use Case digambarkan dengan bentuk abstraksi dari interaksi antara sistem dan actor. Bahasa pemrograman yang digunakan dalam penelitian ini adalah PHP, menurut (Nurmalasari et al, 2019) PHP adalah bahasa pemograman yang digunakan bersamaan dengan HTML dimana bahasa tersebut dijalankan di sisi web browser.

Perancangan User Interface (UI) disini dapat dikatakan sebagai sebuah proses menciptakan media komunikasi yang efektif antara manusia dan computer (Susilo et al, 2018). Pada proses perancangan user interface peneliti menggunakan bahasa pemograman PHP yang merupakan salah satu bahasa yang memiliki sifat server side scripting (Hidayatullah \& Kawistara, 2014) yang disusun agar dapat dijalankan di web server. Menurut (Winarno, 2014) Basis Data atau database merupakan tempat untuk menyimpan data yang jenisnya beraneka ragam, sedangkan untuk database dibuat menggunakan MYSQL, menurut (Novendri et al, 2019) MYSQL merupakan sistem manajemen database yang bersifat relational dan terstruktur, artinya data yang dikelola dalam database yang akan diletakkan pada beberapa tabel yang terpisah sehingga manipulasi data akan jauh lebih cepat. Penelitian ini juga merancang database kedalam skema ERD, menurut (Andriani, 2016; Muntohar, 2020) ERD merupakan sebuah diagram yang menggambarkan hubungan antar entity didalam database, sedangkan menurut (Puspitasari, 2016), "Entity Relationship Diagram (ERD) adalah suatu rancangan atau bentuk hubungan suatu kegiatan di dalam sistem yang berkaitan langsung dan mempunyai fungsi di dalam proses tersebut. Selain ERD, perancangan database juga dapat digambarkan dalam bentuk Logistic Relational Sructur (LRS), dimana menurut Frieyadie dalam (Suryanto, 2016) LRS merupakan hasil dari Entity Relationship (ER) beserta atributnya sehingga bisa terlihat hubungan-hubungan antar entitas. 
Sebagaimana penelitian yang dilakukan oleh (Yuniva et al, 2018) yang membahas mengenai perancangan sistem informasi penjualan produk hasil daur ulang yang ditujukan bagi Ibu-ibu PKK dengan menggunakan metode Waterfall, dimana dalam sistem informasi ini hanya membahas sampai pada menu cetak bukti penjualan atau dalam hal ini hanya sampai proses transaksi utama saja (Fadhlurrahman \& Capah, 2020) juga melakukan penelitian dengan judul Aplikasi Penyewaan Lapangan Futsal berbasis web dengan menggunakan metode Waterfall dengan menyediakan fitur sewa lapangan bagi para calon pelanggan serta memudahkan dalam pengelolaan data sewa lapangan dan data laporan keuangan bagi pemilik lapangan.

Tujuan dari penelitian ini adalah untuk merancang e-commerce sebagai media pemasaran kerajinan bambu pada UKM di desa Brajan, maka dari itu diperlukan sebuah visualisasi internet untuk mempermudah akses ke arsip atau database yang dapat menampilkan informasi, file suara digital, karya seni dan bahkan klip film atau yang dikenal dengan website (Purnama, 2016) agar bisa membantu membuat sistem informasi penjualan bagi UKM Kerajinan Bambu Desa wisata Brajan Sleman guna memasarkan produk yang di produksi supaya produk dari UKM ini dikenal masyarakat luas dan bisa meningkatkan omset penjualan. Selain itu peneliti memberikan kebaharuan dari sistem informasi sejenis yang telah dirancang sebelumnya dengan memberikan tambahan menu Testimoni dari pelanggan yang dimaksudkan untuk memberikan penilaian mengenai produk yang dijual agar dapat menjadi tolak ukur bagi calon pembeli lain sebelum melakukan pembelian.

\section{METODE}

Metode pengumpulan data yang dapat membantu penelitian ini peneliti menggunakan metode pengumpulan data dan metode pengembangan sistem. Pada Metode pengumpulan data dilakukan observasi dan wawancara, sedangkan metode pengembangan sistem difokuskan kearah langkah pembuatan website nya Metode yang digunakan dalam pengembangan sistem ini adalah metode waterfall (air terjun.). Menurut (Rosa \& Shalahuddin, 2015:2) Model air terjun menyediakan pendekatan alur hidup perangkat lunak secara sekuential atau terurut. Secara garis besar metode waterfall pada pembuatan website mempunyai langkah-langkah tahapan-tahapan diantaranya: (1) Perancangan sistem dan Analisis sitem: Proses pengumpulan kebutuhan dilakukan secara intensif untuk menspesifkasikan kebutuhan perangkat lunak yang dibutuhkan oleh user. Pada tahap ini juga dilakukan identifikasi masalah. Beberapa masalah yang ditemukan pada UKM Kerajinan Bambu Brajan yaitu kurangnya promosi dan penjualan masih manual sehingga produk belum bisa dijangkau masyarakat luas mengakibatkan omset penjualan yang tidak sesuai dengan target. Berdasarkan masalah tersebut dapat dianalisis bahwa dengan dibuatnya website ecommerce akan mempermudah promosi dan penjualan produk UKM Kerajinan Bambu Brajan, (2) Desain Sistem: Proses ini berfokus pada struktur data, arsitektur perangkat lunak, representasi, interface, dan detail (algoritma) procedural. Desain website ini menggunakan software enterprise Architect merupakan alat pemodelan dan desain visual berdasarkan UML. (3) Pengkodean Program: Merupakan penerjemahan design dalam bahasa yang bisa dikenali oleh komputer. Dilakukan oleh programmer yang akan menterjemahkan transaksi yang diminta oleh user. Tahap ini peneliti menggunakan bahasa pemrograman PHP dan MYSQL yag dituangkan kedalam software Adobe Dreamweaver CS3 dengan menggunakan XAMPP sebagai web server, (4) Uji Coba Sistem dan Implementasi Sistem: Setelah pengkodean selesai maka akan dilakukan uji coba (testing) serta implementasi terhadap website yang telah dibuat. Dalam pengujian sistem e-commerce penelitian menggunakan metode black box testing. Hal ini dilakukan untuk meminimalisir kesalahan (error) dan memastikan keluaran yang dihasilkan sesuai dengan yang diinginkan, mulai dari analisis spesifikasi untuk perubahan perangkat lunak yang sudah ada tanpa membuat perangkat lunak 
yang baru. (5) Pemeliharaan Sistem: Tindakan yang dilakukan untuk menjaga suatu sistem selalu dalam kondisi yang baik. Tahapan ini dapat dilakukan jika ada masukan dari user.

Teknik pengumpulan data pada penelitian ini meliputi observasi, wawancara dan studi pustaka. Observasi dilakukan dengan cara pengamatan secara langsung dan memperoleh data dari UKM Kerajinan Bambu Brajan dalam pengamatan ini peneliti menemukan beberapa masalah. Selanjutnya peneliti melakukan wawancara dengan mengajukan beberapa pertanyaan mengenai UKM Kerajinan Bambu Brajan dengan Bapak Ngadikin selaku ketua UKM. Dari hasil wawancara tersebut kami mendapatkan informasi mengenai Profil Perusahaan, sistem berjalan, cara pemasaran, produk UKM, kendala yang dihadapi dalam proses promosi dan penjualan. Studi Pustaka disini untuk membantu peneliti menyelesaikan masalah dengan mengacu pada teori dan hasil-hasil penelitian sebelumnya.

\section{HASIL DAN PEMBAHASAN}

Hasil

Berdasarkan tujuan dari penelitian ini yaitu untuk merancang e-commerce sebagai media pemasaran kerajinan bambu pada UKM Kerajinan Bambu Brajan untuk memudahkan dalam pemasaran dan penjualan produk, dikarenakan sistem penjualan yang ada masih sederhana sehingga belum dikenal masyarakat luas. Oleh karena itu solusi yang dihasilkan dari penelitian ini adalah dibuatkanya website e-commerce dengan beberapa fitur. Pada gambar 1 dibawah ini merupakan tampilan Halaman Utama Pengunjung yang belum terdaftar sebagai pelanggan dapat melakukan pendaftaran dengan cara meng-klik tombol mendaftar lalu mengisi data pendaftaran lalu klik simpan. Data email dan password yang sudah tersimpan dapat digunakan untuk melakukan login.

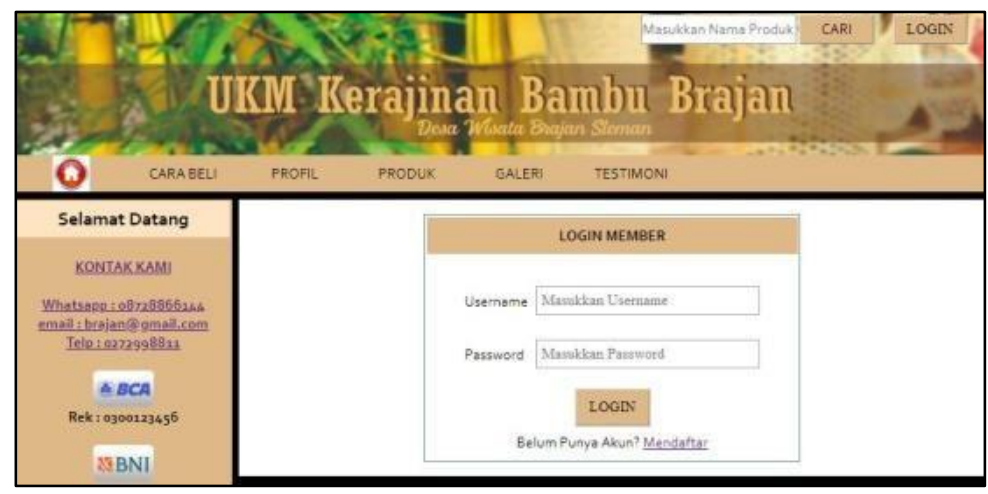

Gambar 1. User Interface Login Pelanggan

Setelah melakukan login jika email dan password sudah benar, maka akan tampil halaman utama seperti pada gambar 2. Ketika pengunjung belum menjadi pelanggan maka seorang pengunjung tidak bisa melakukan pembelian produk produk, mengecek konfirmasi, melihat keranjang belanja, dan menambah taestimoni. Pada halaman ini terdapat fasilitas pencarian produk, selain itu pelanggan yang telah melakukan login dapat melakukan pembelian produk dengan klik beli pada produk yang diinginkan serta melihat detail produk yang dijual. Apabila anggota ingin melakukan pembelian produk, maka pilih menu produk kemudian klik beli pada barang yang diinginkan seperti pada gambar 3. Halaman ini menampilkan semua produk yang dihasilkan oleh UKM kerajinan bambu brajan yang dapat di beli oleh pelanggan yang sudah menlakukan login. Ketika pembeli membeli barang maka barang akan masuk ke keranjang, berikut pada gambar 4 . 


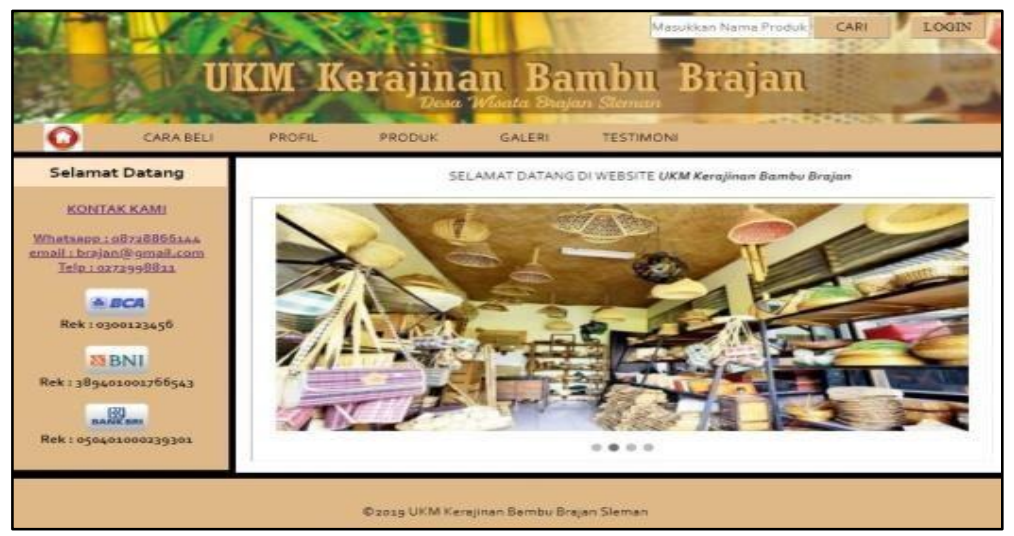

Gambar 2. User Interface Menu Utama

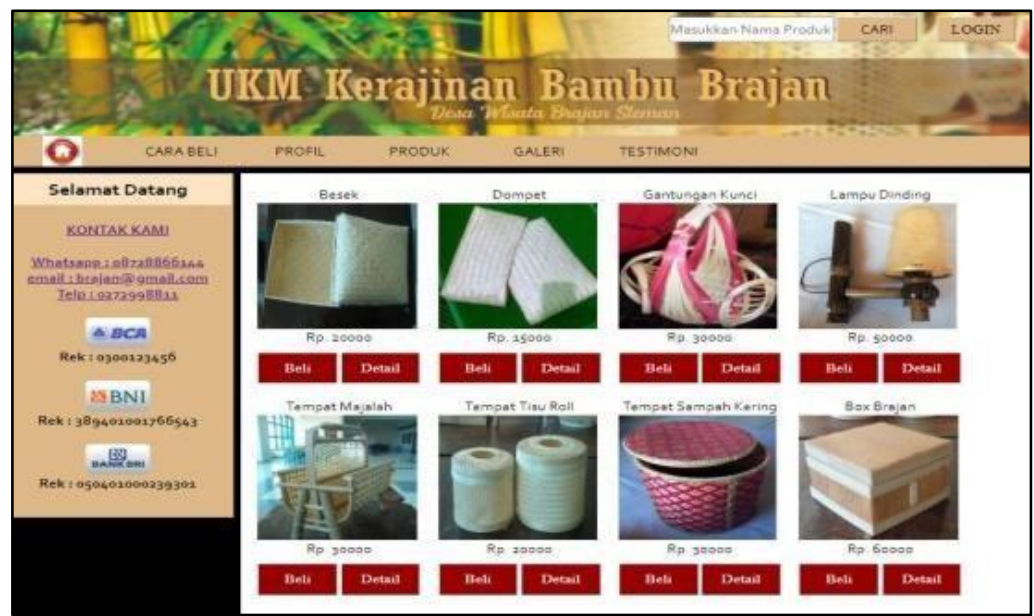

Gambar 3. User Interface Produk

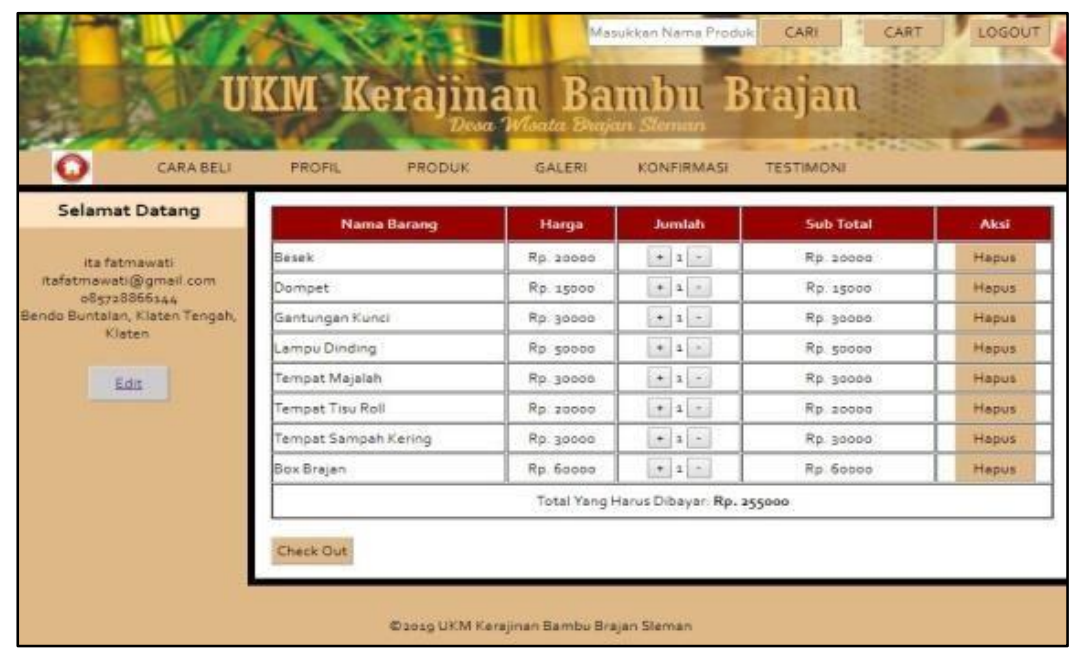

Gambar 4. User Interface Keranjang

Saat pelanggan melakukan klik beli pada produk tertentu, produk tersebut secara otomatis akan masuk kedalam cart/keranjang. Pada halaman ini pelanggan dapat menghapus, menambah dan mengurangi jumlah produk yang akan dibeli. Apabila pelanggan ingin membaca testimoni dari para pembeli dapat langsung klik menu testimoni, maka akan muncul tampilan testimoni dari anggota seperti pada gambar. 5, Anggota dapat menambahkan testimoni produk yang sudah dibeli dengan cara klik button tambah untuk menambahkan testimoni. 
Use Case pada penelitian ini digunakan untuk menggambarkan cara pengguna berinteraksi dengan sistem. Use Case ini terdiri dari 18 Use Case sedangkan aktornya terdiri dari 3 orang, seperti tampak pada gambar 6

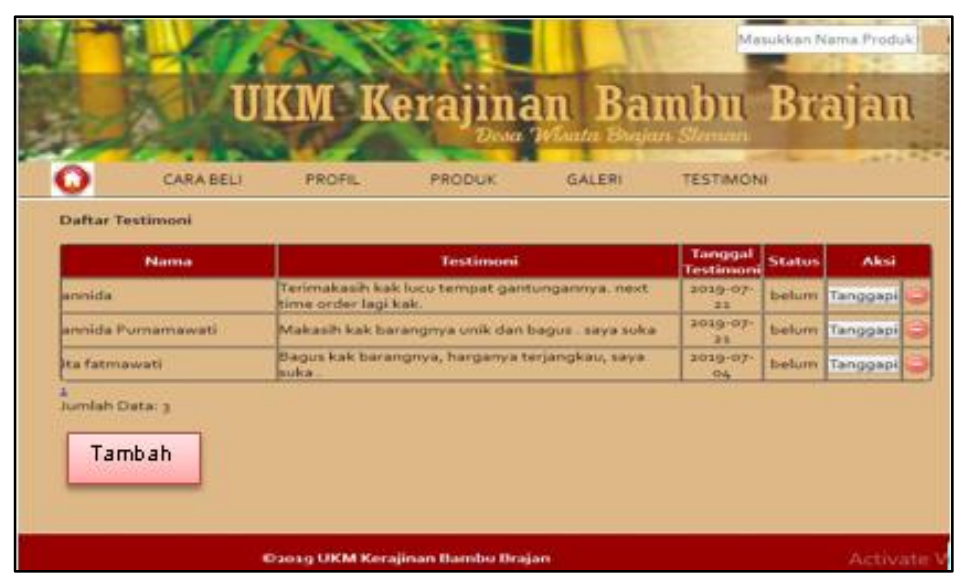

Gambar 5. Testimoni Pelanggan

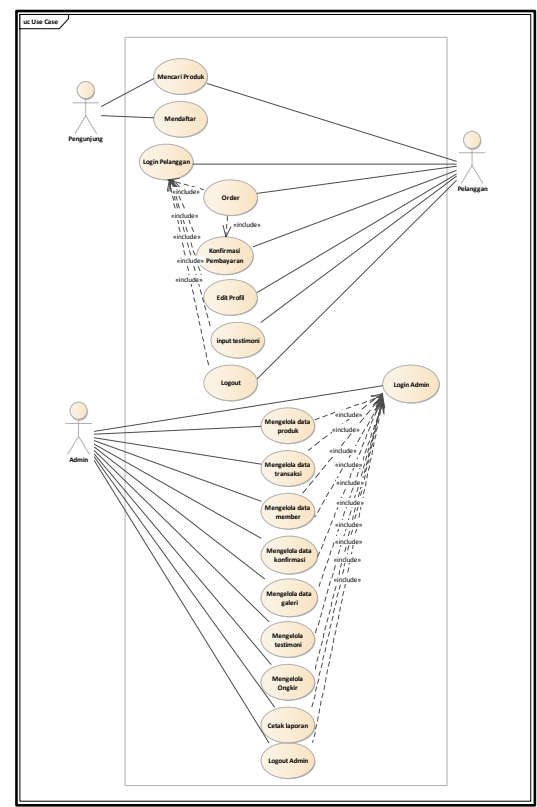

Gambar 6. Use case

Pada penelitian ini juga dirancang activity diagram untuk menggambarkan workflow (aliran kerja) atau aktivitas dari sebuah sistem yang berjalan, diagram ini dibuat dengan tujuan untuk mendeskripsikan logika prosedural seperti gambar 3 yang membahas mengenai activity diagram order. Pada gambar 7 adalah Activity Diagram order dapat diakses oleh pelanggan untuk melakukan pembelian produk.

Pada proses perancangan database disini dimulai dengan mengembangkan skema yang salah satunya dapat menggunakan diagram Entity Relationship (ER Diagram) untuk model relasi dengan implementasi dan Diagram ER. Diagram ini menggambarkan penyusunan basis data dalam bentuk entitas yang merupakan notasi untuk mewakili suatu objek dengan karakteristik seperti tampak pada gambar 8. Berdasarkan ERD pada gambar 8 tersebut, telah dibuat dapat diketahui bahwa dalam perancangan database pada website terdapat 10 Entitas yang digunakan untuk menyimpan data-data berdasarkan kategorinya masing-masing yang didalamnya terdapat detail dari entitas terkait atau biasa disebut dengan Atribut. 


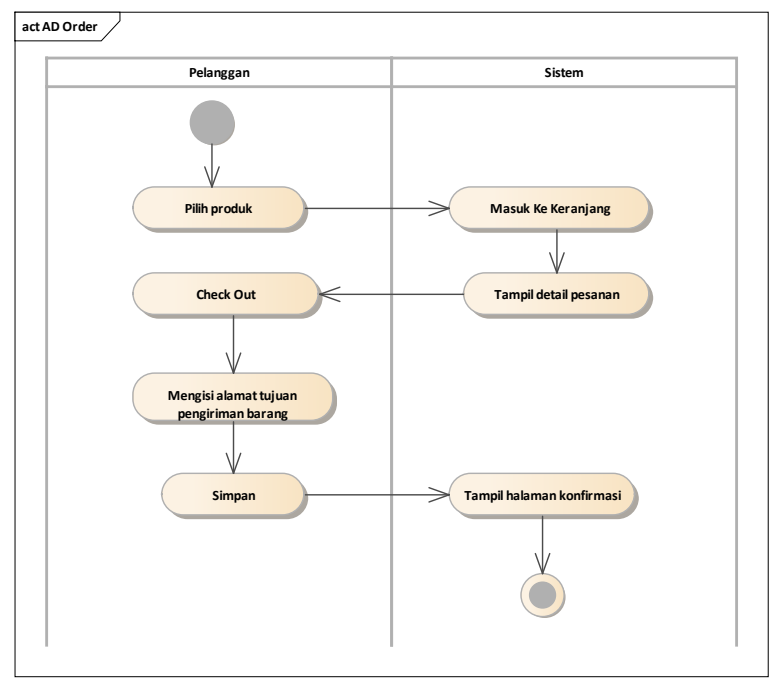

Gambar 7. Activity diagram Order

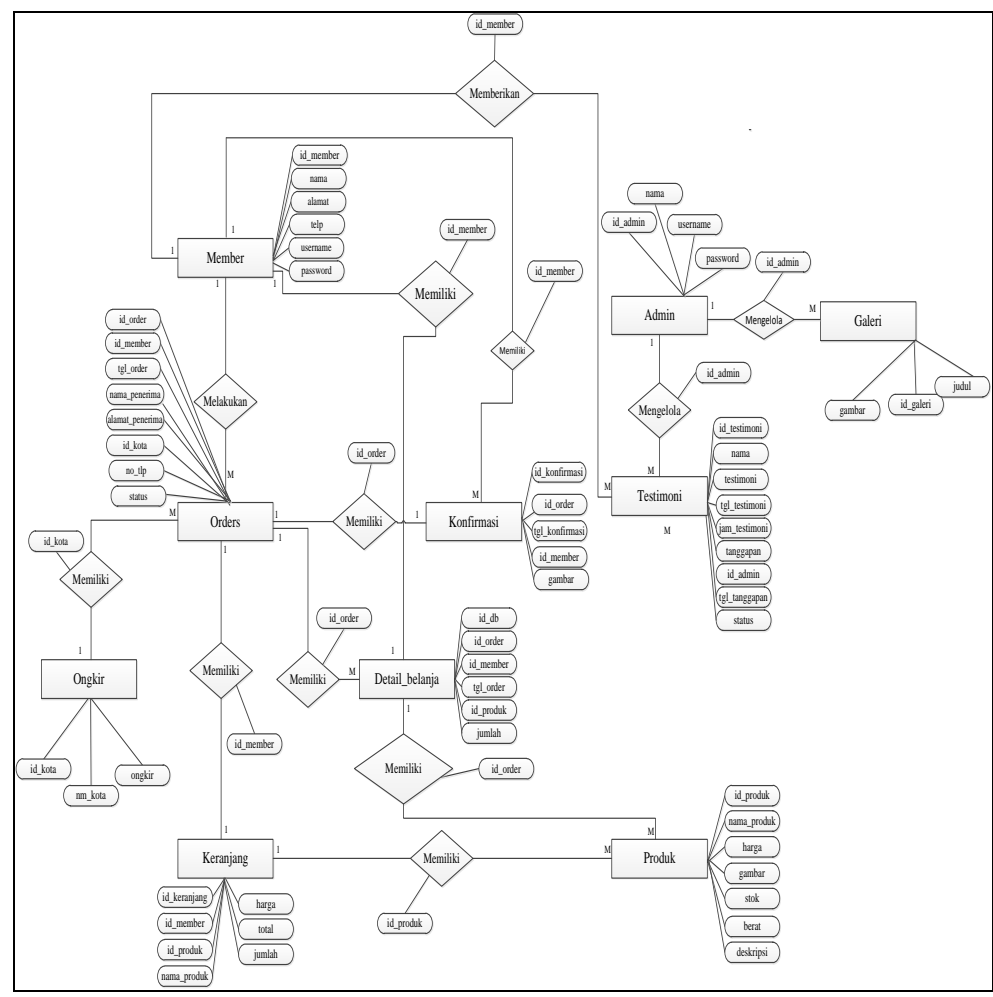

Gambar 8. ERD

\section{Pembahasan}

\section{Hasil Produk}

Pada penelitian ini menghasilkan sistem informasi UKM Kerajinan Bambu Brajan berbasis web yang sebagai media pemasaran yang memudahkan dalam penjualan produk. Seperti yang terlampir pada gambar 1 sampai gambar 4 yang merupakan user interface pada sistem informasi kerajinan Bambu Brajan. Pada gambar 1 merupakan tampilan login pelanggan, pelanggan yang belum menjadi member dapat mendaftar mejadi member dengan cara klik menu member, pelanggan yang sudah menjadi member dapat langsung login dengan cara menginputkan username dan password yang terlah terdaftar, maka secara otomatis pelanggan dapat mengakses sistem tersebut. 
Tampilan gambar 10 memperlihatkan testimoni yang pelanggan berikan terhadap produk maupun kepusan terhadap pelayanan dari website UKM Kerajinan Bambu Brajan. Aplikasi ini telah melewati tahap pengujian, yaitu menggunakan metode black box testing yang bisa dilihat pada tabel 1. Pada gambar 2 merupakan tampilan menu utama atau homepage, pada menu ini pelanggan dapat melihat tata cara pembelian produk, melihat profile UKM Kerajinan Bambu Brajan, Melihat produk beserta deskripsi produk, melihat galeri UKM Kerajinan Bambu Brajan, melakukan pembelian produk produk, mengecek konfirmasi, melihat keranjang belanja serta menambah taestimoni serta dapat melihat testimoni dari pelanggan yang sudah melakukan pembelian sebelumnya. Sementara itu, tampilan pada gambar 3 adalah gambaran produk yang dapat dipilih oleh pelanggan. Apabila anggota ingin melakukan pembelian produk, maka pilih menu produk kemudian klik beli pada barang yang diinginkan, maka secara otomatis produk akan masuk pada menu keranjang belanja. Pada user interface keranjang pelanggan dapat menghapus, menambah dan mengurangi jumlah produk yang sudah dimasukkan ke keranjang seperti tampilan pada gambar 4.

\section{Pengujian}

Tahapan pengujian yang dilakukan pada website UKM kerajinan Bambu Brajan, dilakukan dengan menggunakan blackbox testing. metode ini dipilih dengan harapan agar dapat fokus terhadap masukan dan keluaran program. Pada pengujian terhadap system ini diokuskan pada halaman menu login admin dan pelanggan, daftar member, proses cart, checkout produk, testimoni. Pada tabel 1 telah disajikan data hasil pengujian website menggunakan metode black box testing. Pengujian ini dilakukan dengan mencoba fungsi program dengan memasukkan test case sebagai skenario pengujian terhadap sistem yang telah dibangun kemudian hasil proses tersebut apakah sudah menghasilkan keluaran sesuai dengan harapan yang ditentukan atau belum. Dapat dilihat bahwa semua hasil uji coba sesui harapan (valid). Pengujian difokuskan pada menu login admin dan pelanggan, daftar member, proses cart, checkout produk, testimoni. Pada menu testimoni bisa dilihat bahwa oelanggan yang sudah mendaftar sebagai member dapat memberikan testimoni dengan cara klik button tambah lalu mengisikan nama dan testimoni yang dibuat kemudian klik simpan, secara otomatis testimoni telah ditambahkan. Penelitian yang dilakukan oleh (Yuniva et al, 2018) hanya membahas sampai pada menu cetak bukti penjualan atau dalam hal ini hanya sampai proses transaksi utama saja. Sedangkan (Fadhlurrahman \& Capah, 2020) juga melakukan penelitian dengan judul Aplikasi Penyewaan Lapangan Futsal berbasis web terdapat fitur menu pengajuan sewa alat futsal seperti sepatu dan kostum. Perbedaan antara penelitian terdahulu dan penelitian yang sekarang adalah penelitian yang sekarang terdapat fitur menu testimoni pelanggan fitur ini yang tidak ada pada penelitian sebelumnya.

\section{Deskripsi Use Case Diagram}

Dilihat pada gambar 6 bahwa use case diagram pada website yang dibangun memiliki 3 aktor yaitu pengunjung, pelanggan dan admin. Dimana actor yang terlibat harus login terlebih dahulu untuk dapat mengakses seluruh aktivitas didalam website. Use Case digambarkan bahwa Admin dapat mengelola data produk, data transaksi, data member, data konfirmasi, data galeri, testimoni, ongkir, dan mencetak laporan, pengunjung dapat melihat produk dan mendaftar sebagai member atau pelanggan. sedangkan pelanggan dapat melakukan order, konfirmasi pembayaran, edit profil, dan input testimoni.

\section{Deskripsi Class Diagram}

Pada gambar 8 dapat dilihat, terdapat 10 tabel yang saling berelasi. Misalnya pada gambar 8 diketahui bahwa pada Entitas atau tabel order terdiri dari 8 atribut dimana entitas order berkorelasi dengan salah satunya entitas member dengan aktivitas melakukan, sehingga member dapat melakukan order lebih dari 1 orderan, oleh karena itu koneksi antara member dan order 1 ke $\mathrm{M}$ yang artinya 1 member dapat melakukan banyak order. 
Tabel 1 Hasil Pengujian Blackbox Testing

\begin{tabular}{|c|c|c|c|c|c|}
\hline No & Komponen & $\begin{array}{l}\text { Skenario } \\
\text { Pengujian }\end{array}$ & Test Case & $\begin{array}{l}\text { Hasil Yang } \\
\text { Diharapkan }\end{array}$ & $\begin{array}{c}\text { Hasil } \\
\text { Pengujian }\end{array}$ \\
\hline 1 & $\begin{array}{l}\text { Login oleh } \\
\text { Admin dan } \\
\text { Login } \\
\text { Pelanggan }\end{array}$ & $\begin{array}{l}\text { Mengisi username } \\
\text { dan password } \\
\text { benar, kemudian } \\
\text { klik login. }\end{array}$ & $\begin{array}{l}\text { Username: } \\
\text { admin } \\
\text { Password: } \\
\text { admin }\end{array}$ & $\begin{array}{c}\text { Sistem akan } \\
\text { menerima akses } \\
\text { login, kemudian } \\
\text { menampilkan } \\
\text { "Selamat } \\
\text { Datang!" dan } \\
\text { akan masuk ke } \\
\text { ruang admin } \\
\text { ataupun } \\
\text { pelanggan. }\end{array}$ & $\begin{array}{c}\text { Sesuai } \\
\text { Harapan } \\
\text { (Valid) }\end{array}$ \\
\hline 2 & $\begin{array}{l}\text { Daftar } \\
\text { Member }\end{array}$ & $\begin{array}{l}\text { Semua data diisi } \\
\text { klik simpan }\end{array}$ & $\begin{array}{l}\text { Nama (diisi) } \\
\text { No. Telp (diisi) } \\
\text { Email (diisi) } \\
\text { Alamat (diisi) } \\
\text { Email (diisi) }\end{array}$ & $\begin{array}{l}\text { Sistem akan } \\
\text { menampilkan } \\
\text { "Selamat Anda } \\
\text { Menjadi } \\
\text { Member" }\end{array}$ & $\begin{array}{l}\text { Sesuai } \\
\text { Harapan } \\
\text { (Valid) }\end{array}$ \\
\hline 3 & Proses Cart & $\begin{array}{c}\text { Jika member } \\
\text { menghapus produk } \\
\text { yang dikeranjang } \\
\text { pada saat produk } \\
\text { hanya satu }\end{array}$ & $\begin{array}{l}\text { Produk ada satu } \\
\text { dan dihapus }\end{array}$ & $\begin{array}{c}\text { Sistem akan } \\
\text { menampilkan } \\
\text { "Data di } \\
\text { Keranjang } \\
\text { Kosong, } \\
\text { Silahkan } \\
\text { lakukan } \\
\text { Pembelian" }\end{array}$ & $\begin{array}{l}\text { Sesuai } \\
\text { Harapan } \\
\text { (Valid) }\end{array}$ \\
\hline 4 & $\begin{array}{l}\text { Checkout } \\
\text { Produk }\end{array}$ & $\begin{array}{c}\text { Jika semua data } \\
\text { diisi lalu klik } \\
\text { simpan }\end{array}$ & $\begin{array}{c}\text { Nama (diisi) } \\
\text { Alamat (diisi) } \\
\text { Telepon (diisi) } \\
\text { Kota } \\
\text { (diisi) }\end{array}$ & $\begin{array}{c}\text { Sistem akan } \\
\text { menerima akses } \\
\text { untuk mencetak } \\
\text { bukti transaksi }\end{array}$ & $\begin{array}{l}\text { Sesuai } \\
\text { Harapan } \\
\text { (Valid) }\end{array}$ \\
\hline 5 & Testimoni & $\begin{array}{l}\text { Semua data diisi } \\
\text { lalu klik simpan }\end{array}$ & $\begin{array}{l}\text { Nama (diisi) } \\
\text { Testimoni } \\
\text { (diisi) }\end{array}$ & $\begin{array}{c}\text { Sistem akan } \\
\text { memproses } \\
\text { akses untuk } \\
\text { menyimpan data } \\
\text { testimoni dan } \\
\text { akan } \\
\text { menampilkan } \\
\text { teks "Testimoni } \\
\text { telah } \\
\text { ditambahkan" }\end{array}$ & $\begin{array}{l}\text { Sesuai } \\
\text { Harapan } \\
\text { (Valid) }\end{array}$ \\
\hline
\end{tabular}

\section{SIMPULAN}

Berdasarkan hasil dari rangkaian pengujian terhadap sistem yang dibangun pada Perancangan E-commerce sebagai media Pemasaran Kerajinan Bambu Pada UKM Desa Wisata Brajan Sleman, maka peneliti mengambil kesimpulan bahwa website e-commerrce ini dapat menjadi media sarana untuk mempromosikan dan menyebarkan informasi produk kepada konsumen serta memudahkan transaksi penjualan pada UKM Kerajinan Bambu Brajan. Dengan adanya website ini maka permasalahan yang dialami UKM Kerajinan Bambu Brajan dapat diatasi, sehingga jangkauan pemasaran produk lebih luas, mempermudah 
konsumen dalam melakukan transaksi pembelian produk, yang akan berdampak pada meningkatnya omset penjulan produk UKM Kerajinan Bambu Brajan.

\section{REFERENSI}

Andriani, A. (2016). Manajemen Basis Data. Yogyakarta: Deepublish.

Fadhlurrahman, M. F. F., \& Capah, D. A. H. (2020). Aplikasi Penyewaan Lapangan Futsal Berbasis Web. Edumatic: Jurnal Pendidikan Informatika, 4(2), 30-39. https://doi.org/10.29408/edumatic.v4i2.2412

Handayani, S. (2018). Perancangan Sistem Informasi Penjualan Berbasis E-Commerce Studi Kasus Toko Kun Jakarta. ILKOM Jurnal Ilmiah, 10(2), 182-189. https://doi.org/10.33096/ilkom.v10i2.310.182-189

Hasan, N. P. dan N. (2016). Perancangan Sistem Informasi Administrasi Tamu Hotel (Studi Kasus Pada Hotel Ganesha Purworejo). Journal Speed - Sentra Penelitian Engineering Dan Edukasi, 8(1), 36-43.

Hidayatullah, P. dan J. K. K. (2014). Pemrograman Web. Bandung: Informatika.

Muntohar, A. (2020). Sistem Informasi Data Klien Berbasis Java Pada Kantor Notaris dan PPAT Arif. Edumatic: Jurnal Pendidikan Informatika, 4(2), 58-67. https://doi.org/10.29408/edumatic.v4i2.2515

Novendri, M. S., Saputra, A., \& Firman, C. E. (2019). Aplikasi Inventaris Barang Pada Mts Nurul Islam Dumai Menggunakan Php Dan Mysql. Lentera Dumai, 10(2), 46-57.

Nurmalasari, Anna, \& Arissusandi, R. (2019). Rancang Bangun Sistem Informasi Akuntansi Laporan Laba Rugi Berbasis Web. Jurnal Sains Dan Manajemen, 7(2), 6-14.

Purnama, B. E. (2016). Konsep dasar Internet. Yogyakarta: Teknosain.

Puspitasari, D. (2016). Sistem Informasi Perpustakaan Sekolah Berbasis Web. Jurnal Pilar Nusa Mandiri, 12(2), 227-240.

Rosa AS, M., \& Shalahuddin. (2015). Rekayasa Perangkat Lunak Terstruktur dan Berbasis Objek. Bandung: Informatika.

Soejono, A. W., Setyanto, A., \& Sofyan, A. F. (2018). Evaluasi Usability Website UNRIYO Menggunakan System Usability Scale (Studi Kasus: Website UNRIYO). Jurnal Teknologi Informasi, XIII(1), 29-37.

Suryanto, A. (2016). Rancang Bangun Sistem Informasi Pendaftaran Artis Berbasis Web Menggunakan Model Waterfall. Jurnal Khatulistiwa Informatika, 4(2), 117-126.

Susilo, E., Wijaya, F. D., \& Rudy Hartanto. (2018). Perancangan dan Evaluasi User Interface Aplikasi Smart Grid Berbasis Mobile Application. Jurnal Nasional Teknik Elektro Dan Teknologi Informasi (JNTETI), 7(2), 150-157.

Tohari, H. (2014). Astah-Analissis Serta Perancangan Sistem Informasi Melalui Pendekatan $U M L$. Yogyakarta: Andi Offset.

Triyaningsih, S. L. (2012). Strategi Pemasaran Usaha Kecil dan Menengah. Jurnal Ekonomi Dan Kewirausahaan, 12(1), 37-46.

Winarno, Edy, A. Z. dan S. C. (2014). 24 Jam belajarPHP. Jakarta: Elex Media Komputindo. Yuniva, I., Andriansah, A., \& Maulina, D. J. (2018). Perancangan Sistem Informasi Penjualan Produk Hasil Daur Ulang Sampah Berbasis Website Dengan Pendekatan Metode Waterfall. Jurnal Media Informatika Budidarma, 2(4), 174-180. https://doi.org/10.30865/mib.v2i4.896 